\title{
Isolation, Screening and Characterization of Efficient Drought Stress Tolerant Fluorescent Pseudomonad Isolates from Groundnut (Arachis hypogaea L.) Rhizosphere
}

\author{
B. Prasanna Kumar ${ }^{1}$, N. Trimurtulu ${ }^{2}$, A. Vijaya Gopal ${ }^{2}$, \\ V. Padma ${ }^{2}$ and P. Madhu Vani ${ }^{2}$ \\ ${ }^{1}$ Department of Agricultural Microbiology, APGC, ANGRAU, India \\ ${ }^{2}$ Department of Soil Science, Regional Agricultural Research Station, ANGRAU, \\ Lam, Guntur- 522 034, Andhra Pradesh, India \\ *Corresponding author
}

\section{A B S T R A C T}

\begin{tabular}{|l|}
\hline K e y w o r d s \\
Rhizobacteria, ACC \\
deaminase, $\alpha$ - \\
ketobutyrate, \\
Abiotic stress, \\
Biocontrol, \\
Pseudomonads, \\
Phytohormones \\
\hline Article Info \\
\hline $\begin{array}{l}\text { Accepted: } \\
\text { 12 February } 2020 \\
\text { Available Online: } \\
\text { 10 March } 2020\end{array}$ \\
\hline
\end{tabular}

Fluorescent pseudomonad bacteria, a major constituent of Rhizobacteria, enhance the plant growth through diverse mechanisms. The association between plant and fluorescent pseudomonad bacteria contributes to the successful thriving of plants in extreme environments featured by moisture stress. The enzyme has been noticed in a few numbers of bacteria and which helps the plant growth and development during biotic and abiotic stress situations with the depletion of stress levels of ethylene production in plant system. Fluorescent pseudomonads drawn broad attention as production of secondary metabolites, phytohormones, siderophores, enzymes, antibiotics, HCN and volatile compounds. They can be promoted in low input sustainable agricultural practices. The present experiment revealed that fifty-one efficient bacterial isolates obtained from drought prone rhizosphere soils of groundnut. Isolated strains were also tested for further drought stress screening by poly ethylene glycol 6000 at $0 \%(-0.05 \mathrm{MPa}), 10 \%(-0.65 \mathrm{MPa}), 20 \%(-1.57 \mathrm{MPa}), 30 \%$ $(-2.17 \mathrm{MPa})$ and $40 \%(-2.70 \mathrm{MPa})$. Thirty-seven bacterial isolates were further found to have an enzyme 1-aminocyclopropane-1-carboxylate (ACC) deaminase activity which improved plant growth during stress conditions. Twelve isolates were found to be positive for IAA production. The positive isolates taken and screened for the presence of Fluorescent pseudomonads using King's B media.

\section{Introduction}

The abiotic stress affects the plant-water relations at both cellular and whole-plant level, causing both specific and non-specific reactions and injury. Bacteria can withstand during stress conditions because of production of exopolysaccharides, during water stress conditions (Bashan et al., 2004). Field application of microorganisms having drought-tolerant ACC deaminase may influence the plant growth. The subject of PGPR elicited tolerance to abiotic stresses has been reviewed (Venkateswarlu et al., 2008). 
Some of the PGPR isolates buildup plant stress endurance by ACC deaminase enzyme can contribute significant conservation in a broad range of plants from the injuries caused by various abiotic stress situations. Ethylene synthesis by 1-aminocyclopropane-1carboxylic acid breakdown by ACCdeaminase enzyme which decreases the loss of different stress situations by increasing physiological conditions in the plant roots, at an early stages of stress conditions (Ali et al., 2009).

Pseudomonas sp. is present in wide agricultural soils and has many features that shows these bacteria will be best suited as PGPR. Important fluorescent species like $P$. aeruginosa, $P$. fluorescens, $P$. putida (Bhattacharyya and Jha, 2012), production of secondary metabolites like volatile compound hydrogen cyanide $(\mathrm{HCN})$, phytohormones, , and siderophores, improves plant growth by the increasing of indole-3-acetic acid (IAA), siderophores and antibiotics (Saber and Ramadan, 2015). Pseudomonads of $16 \mathrm{~S}$ rRNA group I having the capability to produce soluble yellow-green pigment pyoverdines (PVDs) or pseudobactins (Bultreys, and Maraite, 2003) which act as siderophores. Fluorescent pseudomonads are considered as effective biological control agents across soil-borne plant pathogens because of their colonization with in the plant roots (Lugtenberg, Dekkers, 1999 and Bloemberg, 2001).

\section{Materials and Methods}

\section{Soil samples collection}

Forty-eight soil samples were collected from different villages of four mandals in the Anantapur (Upland) and Prakasam (Coastal) districts for the isolation of drought stress tolerant bacterial strains. The soil samples were mainly collected from groundnut rhizosphere fields along with their GPS Coordinates. Crop plants were selected randomly in the field and the intact root system was dug out, carefully taken in plastic bags, labeled well and stored at $4{ }^{\circ} \mathrm{C}$.

\section{Isolation of fluorescent Pseudomonad isolates from different rhizosphere soils}

For isolation of Rhizobacteria, the method proposed by Vlassak et al., (1992) was followed. In this procedure, $10 \mathrm{~g}$ of soil from each soil sample was taken in a conical flask of $90 \mathrm{ml}$ saline. The sample was agitated for 15 minutes on a vortex and serial dilutions of soil suspensions were prepared. $0.1 \mathrm{ml}$ was spread on sterilized petri plates containing Nutrient agar media the petri plates were incubated at room temperatures $\left(28{ }^{\circ} \mathrm{C} \pm 2{ }^{\circ} \mathrm{C}\right)$ for 24-72 h. Two replicates were maintained for each dilution. The plates were examined daily up to 3 days for bacterial colonies

\section{Cultural characterization}

The plates incubated for a day at $30 \pm 1{ }^{\circ} \mathrm{C}$ were observed for the growth of fluorescent pseudomonas colonies on Nutrient agar media colonies were further confirmed by using KB plates and the colonies are enumerated manually and recorded. All the bacterial isolates were studied for their colony morphology, cell morphology (Gram reaction), pigmentation, spore production and biochemical characteristics according to the standard methods described in Bergey's Manual of Determinative Bacteriology (Holt et al., 1994 and Cappucino, 1983).

Invitro screening of bacterial isolates for plant growth promoting traits

\section{Drought tolerance}

Trypticase soya broth (TSB) with different water potentials $(-0.05,-0.15,-0.30,-0.49$, 
and $-0.73 \mathrm{MPa}$ ) was prepared by adding appropriate concentrations of polyethylene glycol (PEG 6000) (Michel and Kaufmann 1973; Sandhya et al., 2009) and was inoculated with $1 \%$ of overnight raised bacterial cultures in TSB. Osmotic potential of broth media was measured by a psychrometer. Three replicates of each isolate with each concentration were prepared. After incubation at $28{ }^{\circ} \mathrm{C}$ under shaking conditions $(120 \mathrm{rpm})$ for $24 \mathrm{~h}$, growth was estimated by measuring the optical density at $600 \mathrm{~nm}$ using a spectrophotometer.

\section{EPS production}

Bacterial strains grown on YMG agar medium were inoculated in YMG broth and preincubated at $25{ }^{\circ} \mathrm{C}$ for $24 \mathrm{~h}$. $200 \mu \mathrm{l}$ of culture broth was inoculated into $50 \mathrm{ml}$ of YMG broth and incubated at $25{ }^{\circ} \mathrm{C}$ for 5 days at $120 \mathrm{rpm}$. Elimination of cells was followed by centrifugation $(10,000 \mathrm{~g}$ for $20 \mathrm{~min})$. The culture broth was mixed with 3 volumes of ethanol and after standing at $4{ }^{\circ} \mathrm{C}$ for $24 \mathrm{~h}$, it was centrifuged $\left(10,000 \mathrm{~g}, 4^{\circ} \mathrm{C}, 20 \mathrm{~min}\right)$. The weight of the precipitated EPS was measured after drying at $80{ }^{\circ} \mathrm{C}$ for 3 days (Ali et al., 2013).

\section{Siderophore production}

Siderophore production was estimated at qualitatively. Chrome azurol sulphonate (CAS) agar medium (Schwyn and Neilands, 1987) was used for the detection of siderophores, isolates were grown in synthetic medium, containing $0.5 \mu \mathrm{M}$ of iron and incubated for 24 hrs on a rotary shaker at room temperature. CAS assay is used to detect the siderophores. The CAS plates were used to check the culture supernatant for the presence of siderophores. Culture supernatant was added to the wells made on the CAS agar and incubated at room temperature for $24 \mathrm{hrs}$. Formation of yellow to the orange colored zone around the wells indicates siderophore production.

\section{Indole acetic acid production}

The production of Indole acetic acid was done according to Duby and Maheswari, 2012. LB broth was prepared and $24 \mathrm{hrs}$ old cultures were was inoculated into the broth and incubated at $28{ }^{\circ} \mathrm{C}$ for $72 \mathrm{~h}$. After the incubation period, the cultures were centrifuged at recommended rpm and time. 2 $\mathrm{ml}$ of supernatant was collected into a test tube and two drops of O-phosphoric acid was added. Salkowski reagent was prepared and added into the test tube double the amount of supernatant. To prepare Salkowski reagent 0.4 gms of ferric chloride was added into $5 \mathrm{ml}$ of distilled water and $17.5 \mathrm{ml}$ of perchloric acid was added into $32.5 \mathrm{ml}$ of distilled water and mixed the ratio of 1:150. Incubate the tubes for $30 \mathrm{~min}$ in dark. Development of pink color after the respective incubation period indicates the positive test for IAA production.

\section{Screening for 1-Aminocyclopropane-1- carboxylate (ACC) deaminase activity}

Screening for ACC deaminase activity of drought-tolerant PGPR isolates was done based on their ability to use ACC as a sole nitrogen source. All drought tolerant PGPR isolates were grown in $5 \mathrm{ml}$ of trypticase soya broth (TSB) medium incubated at $28{ }^{\circ} \mathrm{C}$ at 120 rpm for $24 \mathrm{hrs}$. The cells were harvested by centrifugation at $3000 \mathrm{~g}$ for 5 minutes and washed twice with sterile $0.1 \mathrm{M}$ Tris- $\mathrm{HCl}(\mathrm{pH}$ 7.5) and resuspended in $1 \mathrm{ml}$ of $0.1 \mathrm{M}$ Tris$\mathrm{HCl}(\mathrm{pH} \mathrm{7.5)}$ and spot inoculated on petri plates containing modified DF (Dworkin and Foster) salts minimal medium $10 \mathrm{ml}$ and distilled water $990 \mathrm{ml}$, supplemented with 3 $\mathrm{mM} \mathrm{ACC}$ as sole nitrogen source. Plates containing only DF salts minimal medium without ACC as negative control and with $\left(\mathrm{NH}_{4}\right)_{2} \mathrm{SO}_{4}(0.2 \% \mathrm{w} / \mathrm{v})$ as a positive control. 
The plates were incubated at $28{ }^{\circ} \mathrm{C}$ for $72 \mathrm{hrs}$. Growth of isolates on ACC supplemented plates was compared to negative and positive controls and was selected based on growth by utilizing ACC as a nitrogen source (Honma and Shimomura, 1978).

\section{Phosphate solubilizing activity}

Phosphate solubilization activity was determined using Pikovskaya's agar medium $\begin{array}{lllll}\text { containing } & 0.5 & \% & (\mathrm{~W} / \mathrm{V}) & \mathrm{Ca}_{3}\left(\mathrm{PO}_{4}\right)_{2}\end{array}$ (Pikovskaya, 1948). Pikovskayas agar plates were prepared and sterilized. The inoculums were spot inoculated on the pikovskayas plate. $24 \mathrm{hrs}$ old culture was used for the inoculation. The plates were incubated for 72$96 \mathrm{hrs}$ at room temperature. The clear zone was observed around the spotted area after the incubation period.

\section{Potassium releazing ability}

Potassium solubilization determined using Aleksandrov medium containing $0.2 \%$ potassium aluminum silicate (Prajapati and Modi, 2012). KMB media was prepared and sterilized. The $24 \mathrm{hrs}$ old culture was spot inoculated on the KMB plates and incubated for $72 \mathrm{hrs}$ at room temperature. Plates were observed for the clear zone around the spotted area after the incubation period.

\section{Ammonia production}

$10 \mathrm{ml}$ of peptone broth was prepared and sterilized. $24 \mathrm{hrs}$ old culture was inoculated into the broth and incubated for $48 \mathrm{hrs}$ at 30 ${ }^{\circ} \mathrm{C}$ on shaking conditions at $120 \mathrm{rpm}$. Nessler's reagent was prepared and $0.5 \mathrm{ml}$ of Nessler's reagent was added into each test tube. Observation of faint yellow to the brown color in the tubes indicates the presence of ammonia production (Cappuccino and Sherman, 1992).

\section{Results and Discussion}

The serially diluted samples were plated onto Nutrient agar medium further confirmed by using KB media. The colony morphology of the isolates are glistening, smooth, small to medium, convex elevation and were tested further by gram reaction. Among these two bacterial isolates are gram-negative, rods as noticed under a microscope. Among total 12 isolates, two isolates showed yellowish green to light pigmentation, under fluorescent light. Morpho and cultural aspects of the bacterial isolates selected on $\mathrm{KB}$ medium and also recorded pigmentation about thirty colonies were selected, purified and were stored in the refrigerator at $4{ }^{\circ} \mathrm{C}$. Our results agreement with Akter et al., 2014 who isolated 325 bacteria and 14 of them were identified as fluorescent pseudomonads by morphological and biochemical characterization. Fifty Pseudomonas fluorescens and 28 Rhizobium isolates were isolated from rhizospheric soil and root nodules of redgram, identified and characterized biochemically as Rhizobim and Pseudomonas fluorescens (Basha et al., 2014).

\section{Morphological and cultural characteristics of isolates}

Two fluorescent pseudomonas bacterial strains took about $48 \mathrm{~h}$ to show their growth on King's B agar media plate. Isolates are small size, round margin, white, dull white and smooth colonies. Isolates producing yellowish green to light green pigmentation, glistening, opauue, convex, viscid colonies. In the microscopic studies, these isolates exhibited gram -ve nature with single, isolated, rod-shaped cells with no endospores.

\section{Biochemical characterization}

Among two Fluorescent Pseudomonad bacterial isolates, R-14 isolate showed 
positive results for Indole, Ammonia production, Carbohydrate utilization, gelatin hydrolysis, citrate utilization, Indole production, Methyl red test, Starch Hydrolysis and Voges prausker. Isolate K-17 showed positive result- for Ammonia production, Catalase test, Carbohydrate utilization, gelatin hydrolysis, citrate utilization, Oxidase test and Voges prausker (Table 3).

\section{Plant growth promoting properties}

In the table 5 among four bacterial isolates, two fluorescent isolates produced exopolysaccharide production. The isolates were also expressing positive results for siderophores production, ACC deaminase and production of indole acetic acid. Among four isolates, two isolates were showed as maximum PGP properties Among four efficient isolates two isolates i.e R-14 showed P-solubilization Index was $(380.0 \mathrm{~mm})$, followed by K-7 (433.3 mm), K-10 (412.5 $\mathrm{mm})$ and K-17 (228.6 mm). Data on potassium solubilization activity show that out of two isolates, R-14 showed highest solubilization zone $(350.0 \mathrm{~mm})$, followed by $\mathrm{K}-10(316.7 \mathrm{~mm}), \mathrm{K}-7(283.3 \mathrm{~mm})$ and $\mathrm{K}-17$ $(250.0 \mathrm{~mm})$. ACC deaminase enzyme of bacterial origin might be the reduction of ACC deaminase levels in roots, as noticed in previous research. The higher expression of ACS may trigger ACC accumulation in the tissues of the plant, during the initial phase of stress induction. Therefore, the overall result of this cross-talk reveals that the role of IAA to enhancement of plant growth under drought stress. Previous studies revealed that the efficiency of IAA on root length elongation under a drought stress regime.

Recently, Sorty et al., (2016) have reported the influence of bacterial IAA in seed germination and seedling growth in wheat under stress. Further, the phosphatesolubilizing bacterial isolates of drought agrosystems are likely to be more useful for plant health improvement under water deficit conditions.

Table.1 Physico-chemical characteristics of collected soil samples from Anantapur district Andhra Pradesh

\begin{tabular}{|c|c|c|c|c|c|c|c|c|c|}
\hline \multirow[t]{2}{*}{ S.No } & \multirow[t]{2}{*}{ District } & \multirow[t]{2}{*}{$\begin{array}{c}\text { Name of the } \\
\text { mandal }\end{array}$} & \multirow[t]{2}{*}{$\begin{array}{c}\text { Name of the } \\
\text { village }\end{array}$} & \multicolumn{3}{|c|}{ pH } & \multicolumn{3}{|c|}{ 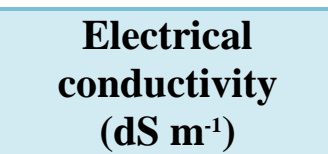 } \\
\hline & & & & $\mathbf{S}_{1}$ & $\mathbf{S}_{2}$ & $\mathbf{S}_{\mathbf{3}}$ & $\mathbf{S}_{1}$ & $\mathbf{S}_{2}$ & $\mathbf{S}_{\mathbf{3}}$ \\
\hline \multirow[t]{8}{*}{1.} & Anantapur & \multirow[t]{2}{*}{ Anantapur } & Alamuru & 6.26 & 6.70 & 6.41 & 0.11 & 0.13 & 0.08 \\
\hline & & & Kateganikalva & 5.68 & 7.24 & 6.40 & 0.07 & 0.16 & 0.08 \\
\hline & & \multirow[t]{2}{*}{ Kambadur } & Andepalli & 6.10 & 5.35 & 8.07 & 0.11 & 0.06 & 0.22 \\
\hline & & & Pallur & 6.18 & 7.89 & 8.13 & 0.06 & 0.17 & 0.20 \\
\hline & & \multirow[t]{2}{*}{ Gummagatta } & Veerapuram & 7.06 & 5.78 & 6.31 & 0.10 & 0.22 & 0.06 \\
\hline & & & Pulakunta & 5.23 & 7.99 & 7.79 & 0.03 & 0.18 & 0.16 \\
\hline & & \multirow[t]{2}{*}{ Vidapanakal } & Vidapanakal & 8.11 & 8.26 & 8.36 & 0.11 & 0.06 & 0.22 \\
\hline & & & V.Kottakota & 8.40 & 8.32 & 8.13 & 0.06 & 0.17 & 0.20 \\
\hline
\end{tabular}

*Values with in the brackets are total rhizosphere soils collected from each village. 
Table.2 Physico-chemical characteristics of collected soil samples from Prakasam district Andhra Pradesh

\begin{tabular}{|c|c|c|c|c|c|c|c|c|c|}
\hline \multirow[t]{2}{*}{ S.No } & \multirow[t]{2}{*}{ District } & \multirow[t]{2}{*}{$\begin{array}{l}\text { Name of the } \\
\text { mandal }\end{array}$} & \multirow[t]{2}{*}{$\begin{array}{l}\text { Name of the } \\
\text { village }\end{array}$} & \multicolumn{3}{|c|}{ pH } & \multicolumn{3}{|c|}{$\begin{array}{c}\text { Electrical } \\
\text { Conductivity }\left(\mathrm{dS} \mathrm{m}^{-1}\right)\end{array}$} \\
\hline & & & & $\mathbf{S}_{1}$ & $\mathbf{S}_{2}$ & $\mathbf{S}_{\mathbf{3}}$ & $\mathbf{S}_{1}$ & $\mathbf{S}_{2}$ & $\mathbf{S}_{\mathbf{3}}$ \\
\hline \multirow[t]{8}{*}{2.} & Prakasam & \multirow[t]{2}{*}{ Chirala } & Thotavaripalem & 7.49 & 7.17 & 6.43 & 0.27 & 0.21 & 0.32 \\
\hline & & & Kavurivaripalem & 6.26 & 5.36 & 5.82 & 0.26 & 0.62 & 0.26 \\
\hline & & \multirow[t]{2}{*}{ Chinaganjam } & Motepalli & 7.21 & 6.82 & 6.41 & 0.49 & 0.33 & 0.45 \\
\hline & & & Kadavakuduru & 5.99 & 6.11 & 6.29 & 0.30 & 0.22 & 0.22 \\
\hline & & \multirow[t]{2}{*}{ Kothapatnam } & Ethamukkala & 7.63 & 7.51 & 7.05 & 0.24 & 0.18 & 0.24 \\
\hline & & & Rajupalem & 8.23 & 6.12 & 5.81 & 0.26 & 0.15 & 0.16 \\
\hline & & \multirow[t]{2}{*}{ Vetapalem } & Akiapalem & 5.48 & 6.52 & 6.53 & 0.16 & 0.16 & 0.17 \\
\hline & & & Kothapatnam & 7.32 & 7.70 & 7.92 & 0.21 & 0.21 & 0.22 \\
\hline
\end{tabular}

* Values with in the brackets are total rhizosphere soils collected from each village

Table.3 Biochemical Characteristics of effective drought stress tolerant

Fluorescent pseudomonad isolates

\begin{tabular}{|l|l|c|c|c|c|}
\hline \multicolumn{1}{|c|}{ S.No } & & $\mathbf{1}$ & $\mathbf{2}$ & $\mathbf{3}$ & $\mathbf{4}$ \\
\hline Isolate Name & & $\mathbf{R - 1 4}$ & $\mathbf{K - 1 7}$ & K-7 & K-10 \\
\hline Ammonia & & + & + & - & + \\
\hline Carbohydrate & Dextrose & + & + & + & + \\
\cline { 2 - 6 } Fermentation & Mannitol & - & - & + & - \\
\cline { 2 - 6 } & Sucrose & - & - & + & - \\
\cline { 2 - 6 } & Lactose & + & - & - & - \\
\hline Catalase & & + & + & + & + \\
\hline Citrate & & + & + & + & + \\
\hline Gelatin & & + & + & + & + \\
\hline H2S & & - & - & - & - \\
\hline Indole & & + & + & - & + \\
\hline Methyl red & & + & - & - & + \\
\hline $\begin{array}{l}\text { Nitrate } \\
\text { reductase }\end{array}$ & & - & - & - & - \\
\hline Oxidase & & - & + & - & - \\
\hline $\begin{array}{l}\text { Starch } \\
\text { Hydrolysis }\end{array}$ & & + & - & + & - \\
\hline Voges Prausker & & + & + & + & + \\
\hline
\end{tabular}


Table.4 Morphological and cultural characteristics of fluorescent Pseudomonads

\begin{tabular}{|c|c|c|c|c|c|c|c|c|c|}
\hline S.No & Isolate & Size & Margin & $\begin{array}{c}\text { Colour of the } \\
\text { colony }\end{array}$ & Elevation & $\begin{array}{c}\text { Surface of the } \\
\text { colony }\end{array}$ & Pigmentation & Gram Stain & Shape \\
\hline 1. & R-14 & Small & Round & White & Convex & Smooth shiny & Yellowish green & -ve \\
\hline $\mathbf{2 .}$ & K-17 & Small & Round & Dull White & Convex & Smooth shiny & Light green & -ve & Rods \\
\hline 3. & K-7 & Small & Undulate & White & Crateriform & Glistening & No pigmentation & -ve & Cocci \\
\hline $\mathbf{4 .}$ & K-10 & Small & Entire & Creamy White & Crateriform & Glistening & No pigmentation & -ve & Small rods \\
\hline
\end{tabular}

Table.5 Plant growth promoting attributes of efficient drought tolerant fluorescent pseudomonads

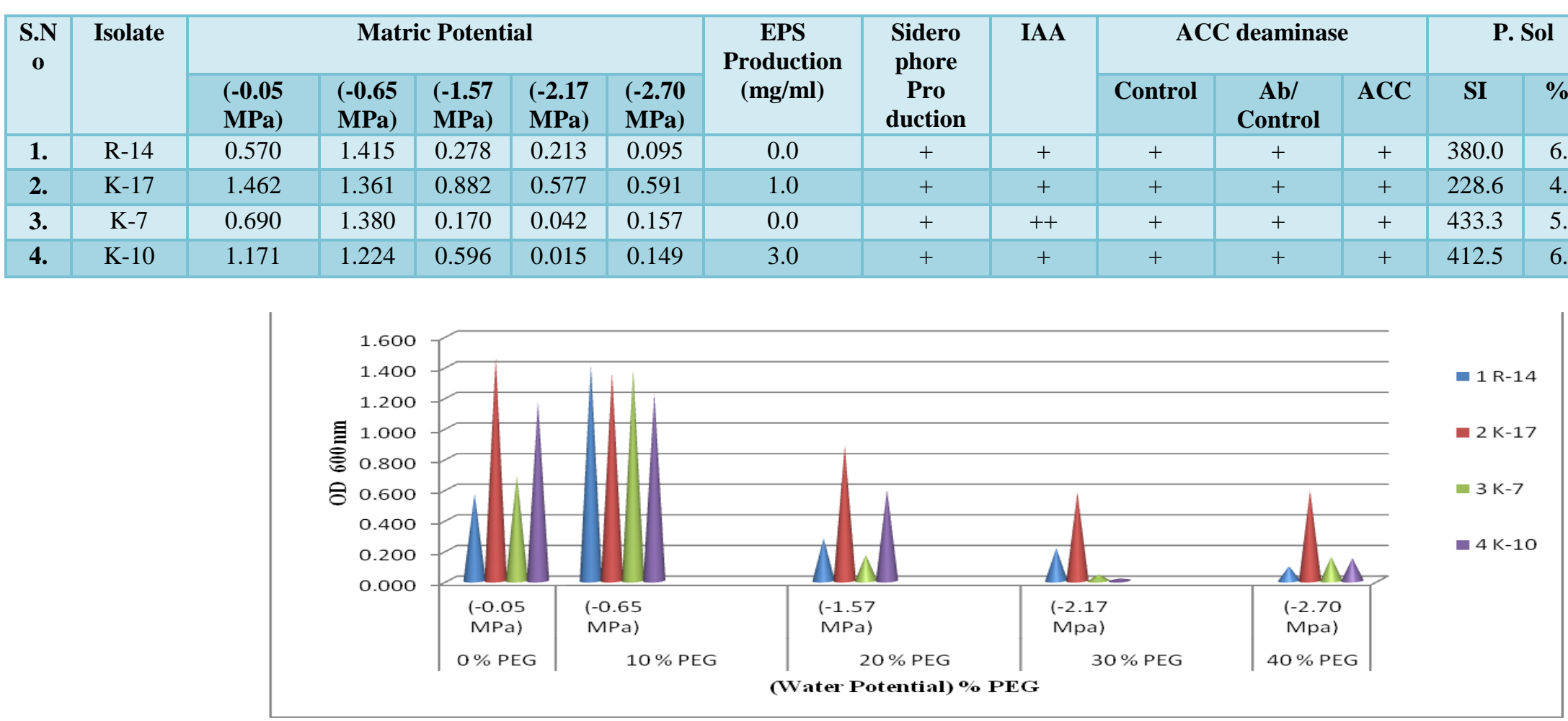

Graph.1 Screening isolates with PEG 6000 

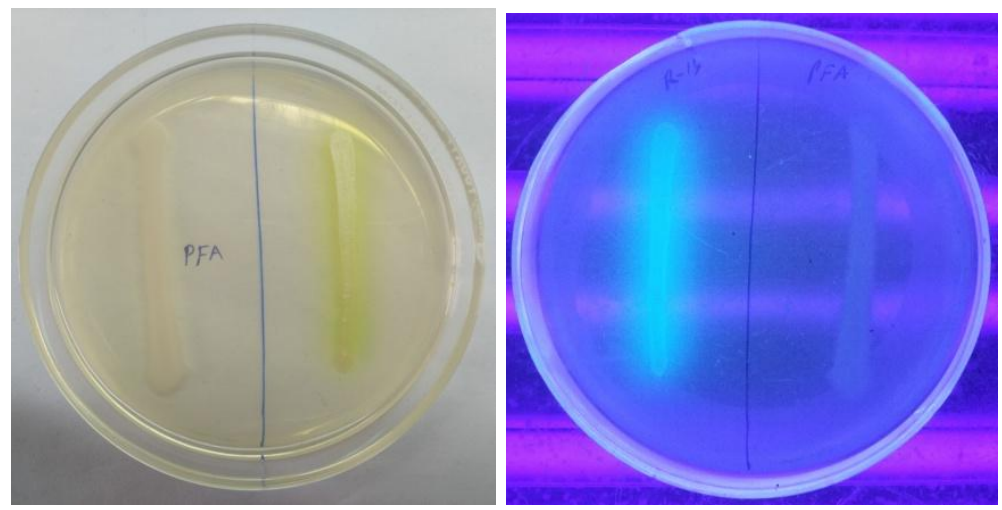

Fig.1 Fluorescent pseudomonas without UV and under UV Transilluminator

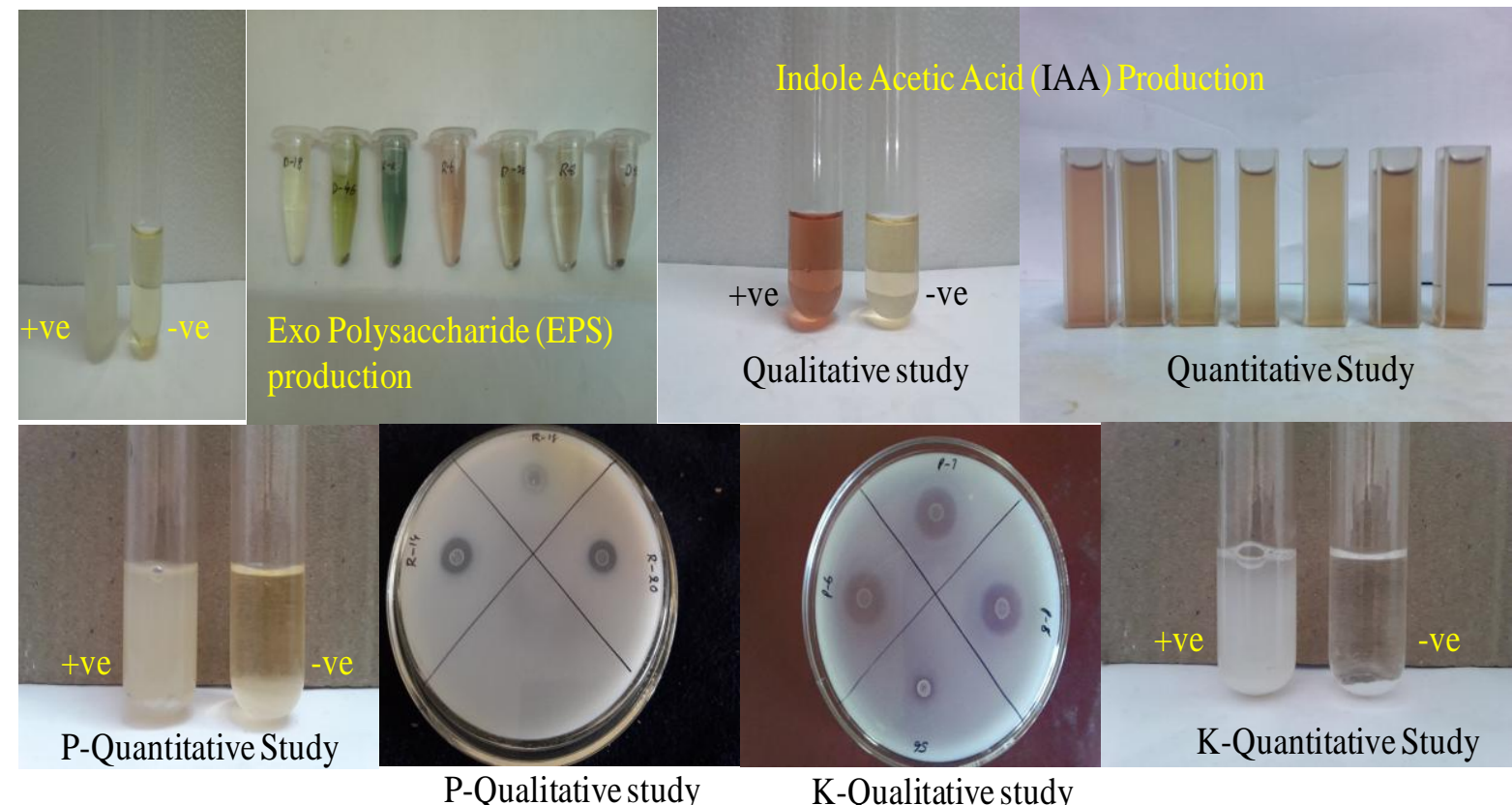

Fig.2 Plant Growth Stimulating Traits

\section{Stress tolerance of fluorescent pseudomonad isolates}

Table 5 shows drought tolerance ability of fluorescent Pseudomonad isolates revealed that, three isolates showed tolerance to water potential from $-0.05 \mathrm{Mpa}$ to $-2.73 \mathrm{Mpa}(0 \%$ to $40 \%$ PEG) R-14 recorded optical density of 0.570 at $0 \%$ PEG (-0.05 MPa), 1.415 at 10 $\%$ PEG (-0.65 MPa), 0.278 at $20 \%$ PEG ($1.57 \mathrm{MPa}), 0.213$ at $30 \%$ PEG $(-2.17 \mathrm{MPa})$ and 0.095 at $40 \%$ PEG (-2.70 MPa). Isolate $\mathrm{K}-17$ recorded as optical density of 1.462 at 0 $\%$ PEG (-0.05 MPa), 1.361 at $10 \%$ PEG ($0.65 \mathrm{MPa}), 0.882$ at $20 \%$ PEG (-1.57 MPa),
0.577 at $30 \%$ PEG (-2.17 MPa) and 0.591 at $40 \%$ PEG (-2.70 MPa). Isolates sceened for drought tolerance (-1.2 $\mathrm{MPa}$ ) showed positive stress tolerance in Pseudomonad strains when compared to other strains (Praveen et al., 2014).

This study suggests that with the application of efficient isolates exhibit a high tolerance to abiotic stress. The peanut roots will have the source for rhizobacteria that are capable of directly protecting plants from drought stress. The above results suggested that positive ACC deaminase bacterial isolates and EPSproducing bacterial isolates are correlated 
with groundnut crop could alleviate drought stress, EPS production by ACC deaminaseproducing bacteria appears to increase the efficiency as PGP bacteria in stress situations, possibly by improving soil structure and bacteria survival.

The isolation and characterization of stresstolerant fluorescent pseudomonad bacteria are not only essential for understanding their characteristics with in rhizosphere but also their utilization in eco-friendly and sustainable agro-technologies.

Besides these mechanisms, the inherent PGP traits of individual bacteria may provide an indirect mechanism for water stress alleviation in the tested plants by providing sufficient phosphate, iron, available nitrogen, and cross-protection against pathogen attack.

The use of such microbial consortium/consortia, which can induce drought stress tolerance and also buildup plant growth promotion during the normal condition, might be very much beneficial for sustainable agriculture.

The integrative application of such consortium having the characteristics of a suitable stresses suppressor is very important aspect for drought stress alleviation in other crops as well.

Moreover, the bacterial strain and their consortium formulation require further field evaluation and validation before being confirmed as bio-inoculants to combat various abiotic stresses in the acidic soil based agroecosystems.

The effective bacterial strains will go a long way in supporting the plant to develop both intrinsic and extrinsic ability to tolerate stressful conditions and sustain yield. In regard to isolates having PGP properties and biocontrol activity, both the fluorescent pseudomonads having drought stress tolerance.

Isolates never showed commonly PGP properties, abiotic stress tolerance and biocontrol activities. fluorescent pseudomonad isolates screened from the research work presented could be screened further under in vitro and in vivo conditions from different soils with several crops for confirming their use as bioinoculants.

\section{Acknowledgment}

Authors would also like to show our gratitude to the members of my advisory members for sharing their pearls of wisdom with us during the course of this research, I am grateful to the advisory committee of Department of Agricultural Microbiology, ANGRAU \& Agricultural Research Station, Amaravathi for their valuable encouragement, many useful discussions and acknowledged the facilities provided for conducting this research smoothly and the financial support extended by the UGC for National fellowship year 2016-17.

\section{References}

Akter, S., Kadir, J., Juraimi, A.S., Saud H.M and Elmahdi, S. 2014. Isolation and identification of antagonistic bacteria from phylloplane of rice as biocontrol agents for sheath blight. Journal of Environmental Biology. 35: 1095-1100.

Ali S. F., Rawat L. S., Meghvansi M. K and Mahna S. K.. Selection of stress-tolerant rhizobial isolates of wild legumes growing in dry regions of Rajasthan, India. ARPN Journal of Agrilcultural and Biological Science. 2009; 4: 13-18.

Ali, S.Z., Sandhya, V, Rao, L.V., 2013. Isolation and characterization of drought tolerant ACC deaminase and 
exo polysaccharide producing fluorescent Pseudomonas sp. Annals of Microbiology. 5, 1-10.

Basha, S.A., Begum, S and Raghavendra. 2014. Search for Agrochemical and Heavy Metal Tolerant Strains of Pseudomonas fluorescens and Rhizobium. Indian Journal of Plant Protection. 42 (1): 71-77.

Bashan, Y., Holguin, $G$ and Bashan, L.E. 2004. Azospirillum plant relationship: physiological, molecular, agricultural and environmental advances. Canadian Journal of Microbiology. 50 (8): 521577.

Belkar, Y.K. and Gade, R.M. 2012. Biochemical characterization and growth promotion activities of Pseudomonas fluorescens. Journal of Plant Diseases and Science. 7 (2): 170174.

Bhattacharyya, P.N., and D.K. Jha. 2012. Plant growth-promoting rhizobacteria (PGPR): Emergence in agriculture. World Journal of Microbiology and Biotechnology. 28:1327-1350

Bultreys A, Gheysen I, Wathelet B, Maraite H, de Hoffmann E. 2003. HighPerformance Liquid Chromatography Analyses of Pyoverdin Siderophores Differentiate among Phytopathogenic Fluorescent Pseudomonas Species. Applied and Environmental Microbiology. 69: 1143-1153.

Cappuccino, J.C.; Sherman, N. Microbiology: a laboratory manual. 3. ed. New York: Benjamin/Cummings Pub. Co., 1992. p. 125-179.

Cappucino, J.G. 1983. Microbiology: A Laboratory Manual. Addison Wesley Publishing Company.

Cheesbrough, M., 2006. District Laboratory Practice in Tropical Countries. $2^{\text {nd }}$ Edn., Cambridge University Press, Cambridge, UK., ISBN-13: 9781139449298.
Dubey, R.C., Maheshwari, D.K., Aeron, A., Kumar, B and Kumar, S., 2012. Integrated approach for disease management and growth enhancement of Sesamum indicum L. utilizing Azotobacter chroococcum TRA2 and chemical fertilizer. World Journal of Microbiology and Biotechnology 28, 3015. Hydroxamate siderophores, 3024.

Fawole, M.O. and B.A. Oso, 2004. Characterization of Bacteria: Laboratory Manual of Microbiology. 4th Edn., Spectrum Book Ltd., Ibadan, Nigeria, pp: 24-33.

Fuchs R, Schäfer M, Geoffroy V, Meyer J.M (2001). Siderotyping - A powerful tool for the characterization of pyoverdines. Current Topics in Medicinal Chemistry. 1:31-35.

Glick, B. R. et al., 2007. Promotion of plant growth by bacterial ACC deaminase. Critical Reviews in Plant Sciences. 26, 227-242.

Holt, J.G., Krieg, N.R., Sneath, P.H.A., Staley, J.T and Williams, S.T. 1994. Bergey's Manual of Determinative Bacteriology, 9th ed, Willams and Wilkins Co. Baltimore.

Honma, $\mathrm{M}$ and Shimomura, T. 1978. Metabolism of 1-Aminocyclopropane1- carboxylic acid. Agricultural and Biological Chemistry. 42: 1825-1831.

Huang, X. F. et al., 2014. Rhizosphere interactions: root exudates, microbes, and microbial communities. Botany. 92, 267-275.

Isenberg, H. D and Sundheim, L. H. 1958. Indole reactions in bacteria. Journal of Bacteriology. 75: 682-690.

Jayashree, K., Shanmugam, V., Raghuchander, T., Ramanathan, $\mathrm{A}$ and Samiyappan, R. 2000. Evaluation of Pseudomonas fluorescens (Pf-1) against blackgram and sesame root-rot disease. Journal of Biological Control. 14: 5561. 
Lugtenberg, B.J., Dekkers, L. and Bloemberg, G.V. 2001. Molecular Determinants of Rhizosphere Colonization by Pseudomonas. Annual Review of Phytopathology, 39: 461-490.

MacFaddin, J. F. Biochemical tests for identification of medical bacteria, $3^{\text {rd }}$ ed. Lippincott Williams \& Wilkins, Philadelphia, PA. 2000.

Michel, B.E., Kaufmann, M.R., 1973. The osmotic potential of polyethylene glycol 6000. Plant Physiology. 51, 914-916.

Olutiola, P.O., O. Famurewa and H.G. Sonntag, 2000. Introduction to General Microbiology: A Practical Approach. 2nd Edn., Bolabay Publications, Ikeja, Nigeria.

Pickett, M.J., Greenwood, J.R and Harvey, S.M. 1991. Tests for Detecting Degradation of Gelatin: Comparison of Five Methods. Journal of Clinical Microbiology. 29 (10): 2322-2325.

Pikovskaya, R.I., 1948. Mobilization of phosphorus in soil connection with the vital activity of some microbial species. Microbiologia. 17, 362-370.

Prajapati, M.C., Modi, H.A., 2012. Isolation of two potassium solubilizing fungi from ceramic industry soils. Life sciences Leaflets. 5, 71-75.

Praveen, G.K., Mir Hassan Ahmed, S.K., Desai, S., Leo, E.D.A., Abdul, R., 2004. In vitro Screening for Abiotic Stress Tolerance in Potent Bio control and Plant Growth Promoting Strains of Pseudomonas and Bacillus spp. International Journal of Bacteriology, 1-6.

Rangaswami, G. and Bagayaraj, D. J. 1993. Microbial biotechnology. In: Agricultural Micro biology. Prentice Hall of India Pvt. Ltd., New Delhi. 389405.

Saber, F.M.A., Abdelhafez, A.A., Hassan, E.A., Ramadan, E.M., 2015.
Characterization of fluorescent pseudomonads isolates and their efficiency on the growth promotion of tomato plant. Annals of Agricultural Sciences. 60, 131-140.

Sandhya, V., Ali, S.Z., Grover, M., Reddy, G., Bandi, V., 2009. Drought-tolerant plant growth promoting Bacillus spp. effect on growth, osmolytes and antioxidant status of maize under drought stress. Journal of Plant Interactions. 6, 1-14.

Schwyn, B., Neilands, J.B., 2003. Universal chemical assay for the detection and determination of siderophores. Analytical Biochemistry. 160, 47-56.

Sorty, A. M. et al., 2016. Effect of plant growth promoting bacteria associated with halophytic weed (Psoralea corylifolia L.) on germination and seedling growth of wheat under saline conditions. Applied Biochemstry and Biotechnology. 180 (5): 872-882.

Sorty, A. M. et al., 2016. Effect of Plant Growth Promoting Bacteria Associated with Halophytic Weed (Psoralea corylifolia L.) on Germination and Seedling Growth of Wheat Under Saline Conditions. Appl. Biochem. Biotechnol. 180 (5), 872-882.

Venkateswarlu B., Desai S and Prasad Y.G. Agriculturally important microorganisms for stressed ecosystems: Challenges in technology development and application'. In: Khachatourians GG, Arora DK, Rajendran TP, Srivastava AK (eds) Agriculturally important Microorganisms, Academic World, Bhopal, 2008; 1: 225-246.

Vlassak, K.L., Van, $\mathrm{H}$ and Duchateau, L. 1992. Isolation and characterization of fluorescent Pseudomonas associated with the roots of rice and banana grown in Srilanka. Plant and soil. 145: 51-63. 
How to cite this article:

Prasanna Kumar. B, N. Trimurtulu, A. Vijaya Gopal, V. Padma and Madhu Vani. P. 2020. Isolation, Screening and Characterization of Efficient Drought Stress Tolerant Fluorescent Pseudomonad Isolates from Groundnut (Arachis hypogaea L.) Rhizosphere. Int.J.Curr.Microbiol.App.Sci. 9(03): 1593-1604. doi: https://doi.org/10.20546/ijcmas.2020.903.187 